○寺師 隆也・增野 豊

本院受揨患者約 400 例を推計し，大腿軸一傣関節顆間

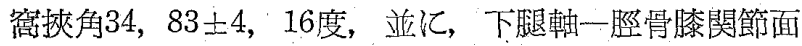

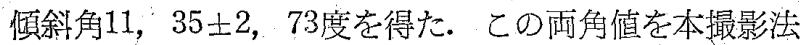

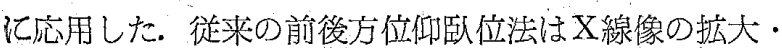
フイルムの位置付けの不備力゙あり，後前方位腹臥位法は 患部の加重により疼痛えの他を生じ，体位がとり難い久 点がある. 当院では，患者の体位は患側在下に正側卧位 Kし，大腿，下腿軸を正しく側方位，フイルムを撮影台 に垂直にし，X線管球は後前方位，大腿軸，下腿軸は， 前記推計值を用いて撮影老行うことにより，従来の撮影 体位に見られる欠点を補修し，安易な撮影体位で好結果 を得ているので報告する.

\section{Guthmann 撮影法における一工夫}

北九州市立小倉病院

○吉瀬 孝志・原本 輔一山山口 昇

\section{7. 多軌道断層による腰椎撮影とその再現性に関する 問題}

\section{中部労炎病院放射線科}

○植村 修・浅茾，英博・稻垣，良美 青木 豊・新田 義勝、安藤、嘉康

体位を変えずに患者を仰臥位のままで腰椎斜位を撮影 する方法。(1)装固の天板を上下に移動し，X線问転軸と 腰椎々体の中心とを合わせる，(2)装置の天板を左右に移 動させ，X線を腰椎々体の中心へ合わせる。この二つの 方法である，撮影時にはIVPのときと同橡に腹部を压 迫すれば良好な写真效果が得られ，また被曝量を軽減さ れる。利点は，(1)再現性が優れている。骨の歪みは診断 上問題とならない。(2)被曝量軽娍。(3)患者の負担が少な い.（4)撮影取り扱いが簡単で，短時間で撮影がでさる.

また一般の外科用撮影装置です特製の夫板さえ作れば この方法による撮影は可能である。

\section{8. 経験的アスベスト肺症の撮影法}

神奈川慁予防医学協会

$$
\begin{aligned}
& \text { ○向井 豊・荻原 明・本條 八洋 } \\
& \text { 高橋 公二・武井：恒夫・樋口政昭 } \\
& \text { 四中 耕策・名波 明尋・柏木さと美 }
\end{aligned}
$$

最近職業病の一つとしてアスベスト肺が問題となつて きている.アスベスト肺の特徽として啝膜肥厚や横隔膜 の石死沈着が多〈みられるととを考慮し，適正な撮影法 について検討した。第 1 斜位，第 2 斜位も加え体位の検 討す試みたが，アスベスト脑には胁膜肥曆が多いととが 確認され，肋膜肥厚はアスベスト肺発見の一要团になる と考えられる. したがってアスベスト肺のX線㝍真とし
ては，肺野はもちろんのとと朐膜肥暻を良好に示現さ せる必要がある，直接高压撮影加望ましく，末た背腹正 面に浅い斜位（第1または第 2 ）を抈えた 2 方向撮影を 行うと，肋膜肥厚の示現が高くなり診断に有利になるで あるう。

\section{9. オルソパントモグラフ装置による顎骨側斜位撮影 について \\ 大阪大学筜学部附属病院歯科放射線科 \\ ○角田 明 \\ 大阪大学菌学部歯科放射線学教室}

$$
\text { 上村修三郎 }
$$

粜牙，顎骨だけを選択的に撮影するには骨構造が複染隹 なため，正側面方向の撮影だけでは十分でないととが多 く，日腔領域ではオルソパントモグラフィが沉用されて いる.しかしより病変の細部の情報炎得るには側斜位撮 影は久かせない撮影法の一つである. との撮影法は患者 の体位，カセッテの固定，管球入射角度の選定などに熟 練を要し，また再現性化も之しい. 本研究では瞄成の才 ルソパントモグラフ装置を利用し顎骨の側斜位撮影を試 みた結果, 從来の方法と比較して前述の体位, 固定, 角 度の選定が容易となり，像の歪みが比較的少なく，かつ 再現性があるため，本法は顎骨の撮影ならびにX線診断 に有意義であると考えられた。

\section{座長集約}

この演題群は実際の撮影法に関するあので, 誌上 4 題 (No.14，15，16，17), 口述 2 題（No.18，19）であっ た。

演題14は最近閥題となっている滕蓋骨軟骨軟化症のX 線学的䛦断の基準化を計るため，槂関節の各屈出角度に よる側面 $\mathrm{X}$ 線像より，大腿骨䭯と㯟蓋骨軸，膝䕊骨軸と 脛骨軸などの䦔係を統計的に推圾し， pattello-femoral joint を観察する滕蓋骨軸位撮影法に利用しようとした ものである.これらの計測值は今後の撮影法の基礎をな すむので，また変化を含めた形態的診断の基準化を進め る上で大変参考になる。座長より，乙れらのデータを臨 床的に利用する場合，体位，負荷状態，固定具等どうし たら良いかとの質問には目下検討の段階であると回答さ れた。臨床での応用は負荷の状態，再現性，その時の固 定具などを含めて容易で正確な撮影法を考案されるよう 望みなりすのである.

演題 15 も同じく膝関節のX線像より，大腿骨軸一滕関 節面傾斜角を推計し，膝関節顆間蛧撮影に応用したもの である．撮影体位は思者の安楽を中心に考えたもので， 